\title{
Regulation of the expression and secretion of urocortin 2 in rat pituitary
}

\author{
Takahiro Nemoto, Azusa Iwasaki-Sekino, Naoko Yamauchi and Tamotsu Shibasaki \\ Department of Physiology, Nippon Medical School, 1-1-5 Sendagi, Bunkyo-ku, Tokyo 113-8602, Japan \\ (Requests for offprints should be addressed to T Nemoto; Email: taknemo@nms.ac.jp)
}

\begin{abstract}
We previously demonstrated that urocortin 2 (Ucn 2) is expressed in the proopiomelanocortin (POMC) cells of rat pituitary. However, the regulatory mechanism of pituitary synthesis and secretion of Ucn 2 remained to be clarified. We hypothesized that hypothalamic hormones and glucocorticoids may control the expression and secretion of pituitary Ucn 2, as Ucn 2 is expressed in POMCexpressing cells in the pituitary. Thus, in the present study, we tested this hypothesis using primary culture of rat pituitary cells. The secretion of Ucn 2 from the anterior and intermediate pituitary cells was significantly increased by $50 \mathrm{mM} \mathrm{KCl}$. In the anterior pituitary cells, corticotropin-releasing factor (CRF) increased mRNA expression levels and secretion of $\operatorname{Ucn} 2$, although arginine vasopressin (AVP) did not induce any significant change
\end{abstract}

in Ucn 2 expression or secretion. Under these conditions, both CRF and AVP increased ACTH secretion, but only CRF increased the level of POMC mRNA expression. Dexamethasone inhibited Ucn 2 and POMC mRNA expression levels, while it inhibited the secretion of only Ucn 2. In the intermediate pituitary, CRF increased both the mRNA expression levels and secretion of Ucn 2 . Furthermore, dopamine did not affect either the mRNA expression level or secretion of Ucn 2 although it inhibited $\beta$-endorphin secretion in the intermediate pituitary cells. These results suggest that the mRNA expression and secretion of Ucn 2 in POMC cells of the pituitary are positively regulated by CRF and negatively regulated by glucocorticoids.

Journal of Endocrinology (2007) 192, 443-452

\section{Introduction}

As a member of the corticotropin-releasing factor (CRF) family peptides, urocortin (Ucn 1) was discovered by screening of a rat brain cDNA library with a probe derived from carp urotensin I (Vaughan et al. 1995). Human stresscopin (SCP) and stresscopin-related peptide (SRP; Hsu \& Hsueh 2001) and mouse Ucn 2 and Ucn 3 (Lewis et al. 2001, Reyes et al. 2001) corresponding to SRP and SCP respectively were then simultaneously discovered as new members of the CRF family peptides. The actions of these CRF family peptides are mediated by its two receptor subtypes, $\mathrm{CRF}_{1}$ and $\mathrm{CRF}_{2}$ receptors (Chen et al. 1993, Liaw et al. 1996, Kostich et al. 1998, Wang et al. 2004, Chen et al. 2005). The $\mathrm{CRF}_{2}$ receptor is further divided into two isotypes $(\alpha$ and $\beta$ ) in rodents. Ucn 1 has higher affinities for both the $\mathrm{CRF}_{1}$ and $\mathrm{CRF}_{2}$ receptors than for CRF, while $\mathrm{Ucn}$ 2 and $U \mathrm{cn} 3$ are considered endogenous ligands for the $\mathrm{CRF}_{2}$ receptor, as they show specific affinities for the $\mathrm{CRF}_{2}$ receptor (Hsu \& Hsueh 2001, Reyes et al. 2001).

An immunohistochemical study has shown that Ucn 2-like immunoreactivity is present in the posterior pituitary and atria of mice (Hsu \& Hsueh 2001), while reverse transcription PCR (RT-PCR) analysis of Ucn 2
mRNA expression has indicated that Ucn 2 is expressed in various human peripheral tissues such as the heart, kidney, spleen, lung, muscle, stomach, testis, thyroid, placenta, adrenal glands, and blood cells (Reyes et al. 2001, Tanaka et al. 2003). Another recent study, in mice, has shown that Ucn 2 is strongly expressed in skin and skeletal muscle, but weakly expressed in the adrenal glands, stomach, ovary, testis, thymus, brown fat, spleen, and lungs (Chen et al. 2004). We have also previously shown that Ucn 2 is distributed in various tissues of rats including the anterior and intermediate pituitary and the adrenal glands, and that Ucn 2-positive cells in the anterior and intermediate pituitary are also positive for $\beta$-endorphin, indicating that Ucn 2 is synthesized in proopiomelanocortin (POMC) cells of the pituitary (Yamauchi et al. 2005). However, the regulatory mechanisms involved in the synthesis and secretion of Ucn 2 by the pituitary remain unknown. Thus, using primary cultured anterior or intermediate lobe cells of rat pituitary, we examined whether mRNA expression and secretion of pituitary Ucn 2 is affected by CRF, vasopressin, dopamine and glucocorticoids, which influence the synthesis and secretion of POMC-derived peptides. 


\section{Materials and Methods}

\section{Reagents}

DMEM/F12 media, dopamine, and dexamethasone were purchased from Sigma-Aldrich (St Louis, MO, USA). CRF and Ucn 2 were obtained from the Peptide Institute (Osaka, Japan) and the Yanaihara Institute (Shizuoka, Japan) respectively.

\section{Animals}

Male Wistar rats weighing $160 \mathrm{~g}$ were used for all experiments. All experimental procedures were conducted in accordance with the guidelines on the use and care of laboratory animals approved by the Local Animal Ethics Committee of Nippon Medical School, Japan.

\section{Primary culture of pituitary cells}

Thirty rats were killed by decapitation and their pituitary glands were removed under sterile conditions. The anterior and intermediate/posterior pituitaries were separately collected, and mechano-enzymatically dispersed as described previously with modifications. Briefly, pituitaries were minced in a 1:1 mixture of DMEM and Ham's nutrient mix F-12 containing 10\% FCS, penicillin and streptomycin (DMEM/F12; Sigma-Aldrich). Samples were then washed twice in PBS and then incubated at room temperature in the PBS containing $0.047 \mathrm{~g} / 1 \mathrm{MgCl}_{2}$, $0 \cdot 1 \mathrm{~g} / \mathrm{CaCl}_{2}$, and $0 \cdot 01 \%$ dispase (Godoshusei, Tokyo, Japan) with constant stirring for $30 \mathrm{~min}$. A $1 \mathrm{ml}$ aliquot of cell suspension containing $1.0 \times 10^{4}$ cells in a DMEM/F12 was placed in each well of 24-well plates. The anterior and intermediate pituitary cells obtained from 30 rats were cultured in 72 and 18 wells respectively. The cells were subsequently allowed to attach to the surface of the wells in a humidified 95\% air- $5 \% \mathrm{CO}_{2}$ incubator for 4 days. On the day of the experiment, the culture medium was changed. The cells were incubated for $4 \mathrm{~h}$ with the prepared samples and the culture medium from each well then collected. After centrifugation to remove debris at 3500 r.p.m. for $10 \mathrm{~min}$ at $4{ }^{\circ} \mathrm{C}$, the culture media from each sample was frozen and kept at $-20{ }^{\circ} \mathrm{C}$ until assay. Adrenocorticotropic hormone (ACTH) in the culture medium was measured using an ACTH IRMA kit (Mitsubishi Kagaku Iatron, Tokyo, Japan). $\beta$-Endorphin was measured using a high sensitivity EIA kit for rat $\beta$-endorphin (Peninsula Laboratories, Inc, San Carlos, CA, USA). Cultured anterior or intermediate lobe cells were homogenized in deionized water by a sonicator and the supernatant after centrifugation was assayed with RIA for Ucn 2 to test its parallelism with the standard curve. Monolayer culture of rat anterior and intermediate pituitary cells was performed six times, and 180 rats in total were used.

\section{RIA for Ucn 2}

RIA for Ucn 2 was performed as reported previously (Yamauchi et al. 2005). Synthetic mouse Ucn 2 was
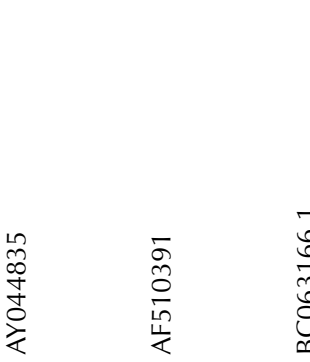



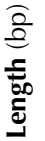

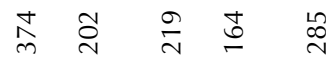

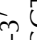
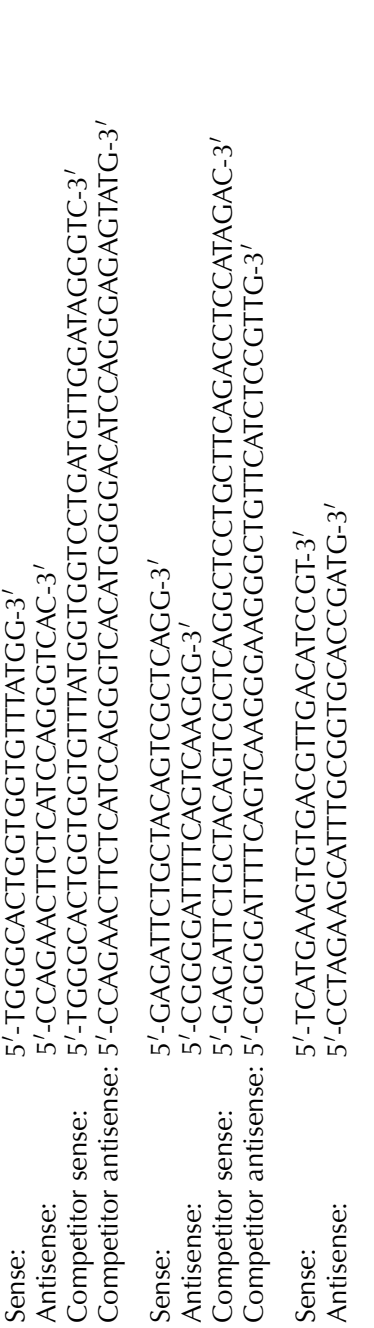

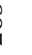

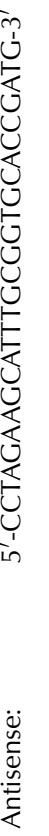




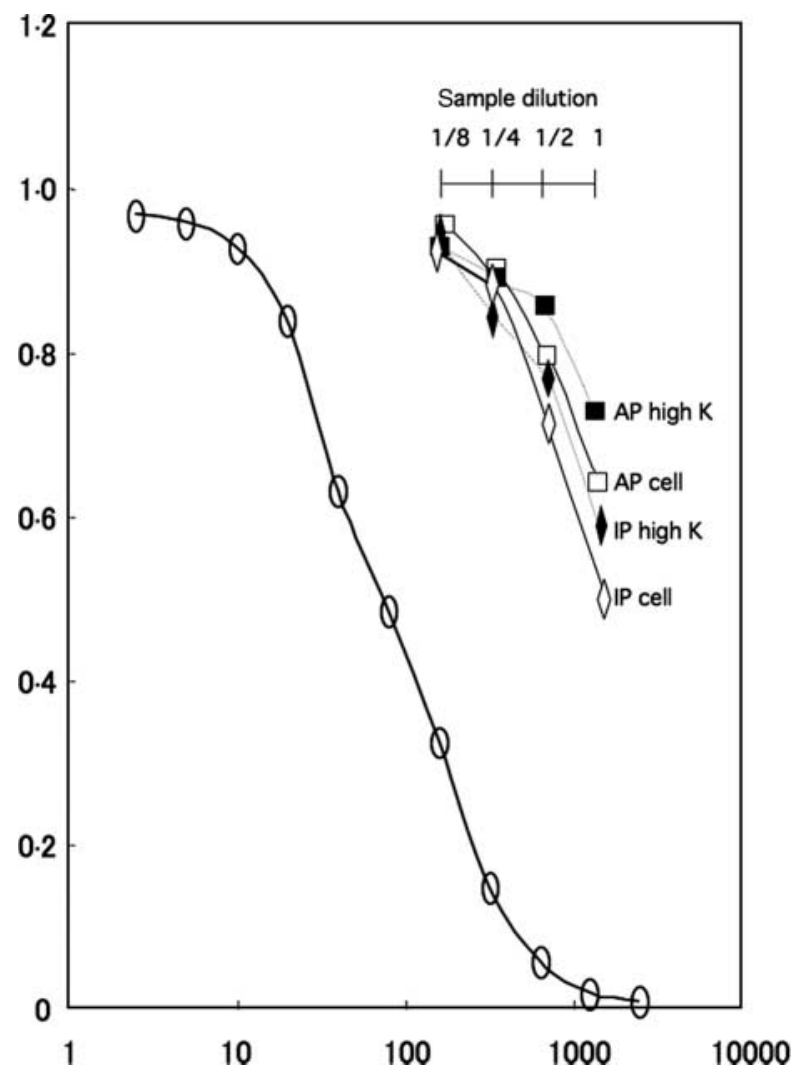

Figure 1 A standard curve of RIA for Ucn 2 and dilution curves of culture media and extracts of anterior and intermediate lobe cells. AP high $\mathrm{K}$ and IP high $\mathrm{K}$ indicate culture media in which anterior and intermediate pituitary lobe cells were incubated with $50 \mathrm{mM} \mathrm{KCl}$ respectively for $4 \mathrm{~h}$. AP and IP cells indicate the extracts of cultured anterior and intermediate pituitary lobe cells respectively.

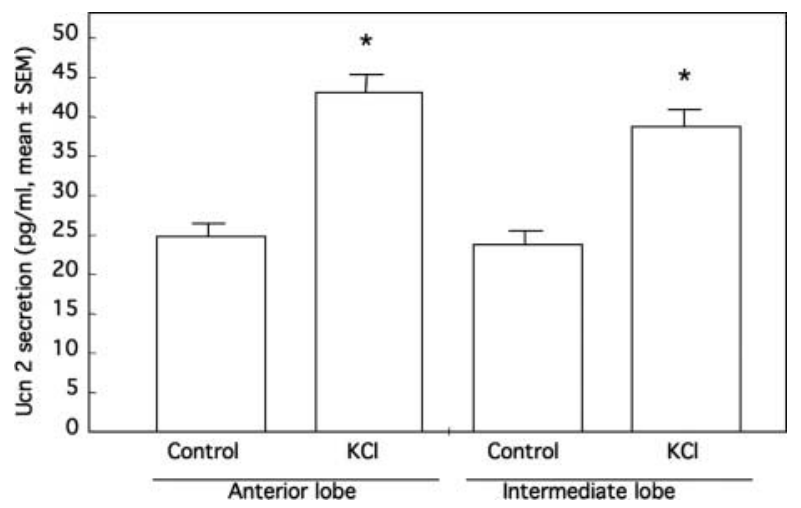

Figure 2 U cn 2 is secreted from anterior and intermediate pituitary cells. Anterior and intermediate pituitary cells were treated with $50 \mathrm{mM} \mathrm{KCl}$ for $4 \mathrm{~h}$. After incubation, culture media were collected and assayed for Ucn 2 using RIA with a specific antibody against mouse $U_{\mathrm{cn}} 2$. U $\mathrm{cn} 2$ concentrations in culture media are shown as means \pm S.E.M. The number of wells for each treatment was 12 . $* P<0 \cdot 05$, compared with control. iodinated using the chloramine- $\mathrm{T}$ method and purified on a column of Sephadex G-50 as previously described (Shibasaki et al. 1984). PBS ( $\mathrm{pH} 7 \cdot 5$ ) containing $0 \cdot 01 \%$ NP-40 (Nacalai Inc., Kyoto, Japan), 5 mM EDTA-Na, and $0 \cdot 02 \%$ sodium azide was used for RIA. Synthetic mouse Ucn 2 or sample was incubated with anti-Ucn 2 antiserum (SR-6) in $5 \mathrm{ml}$ plastic tubes for $24 \mathrm{~h}$ at $4{ }^{\circ} \mathrm{C} .{ }^{125}$ I-Labeled Ucn 2 (5000 c.p.m.) was then added to each tube and incubated for another $24 \mathrm{~h}$ at $4{ }^{\circ} \mathrm{C}$. Goat anti-rabbit $\gamma$-globulin was used to separate tracer bound to antiserum from free tracer. The anti-Ucn 2 serum was used for RIA at a final concentration of $1 / 350000$ to yield a maximum binding of approximately 30\%. The cross-reactivity of the antiserum with rat CRF was $0 \cdot 0 \%$ at $\mathrm{ED}_{50}$ (Yamauchi et al. 2005).

A
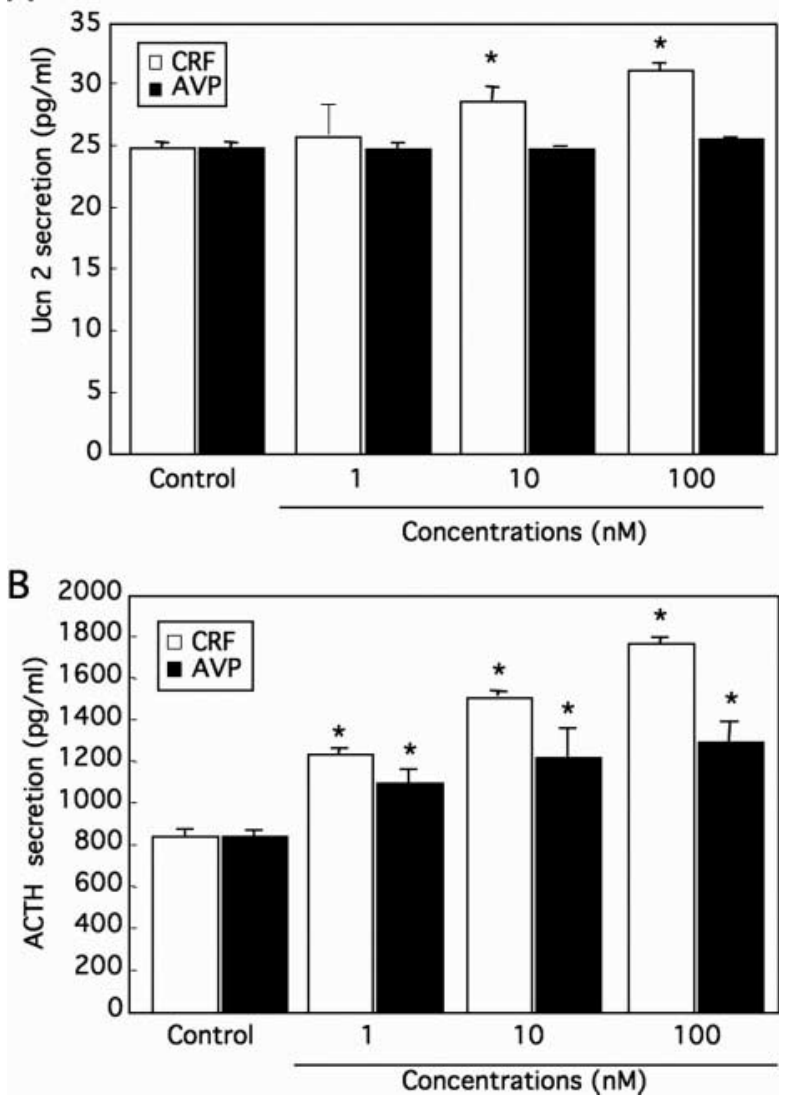

Figure 3 CRF induces Ucn 2 secretion from anterior pituitary cells. Anterior pituitary cells were treated with CRF or vasopressin at concentrations ranging from 1 to $100 \mathrm{nM}$ for $4 \mathrm{~h}$. After incubation, culture media were collected and assayed for Ucn 2 using RIA with a specific antibody against mouse Ucn 2 (A) and ACTH using an ACTH IRMA kit (B). The concentrations of Ucn 2 (A) and ACTH (B) are shown as means \pm s.E.M. The numbers of wells for each treatment in Ucn 2 and ACTH assay were 24 and 12 respectively. $* P<0 \cdot 05$, compared with control. 

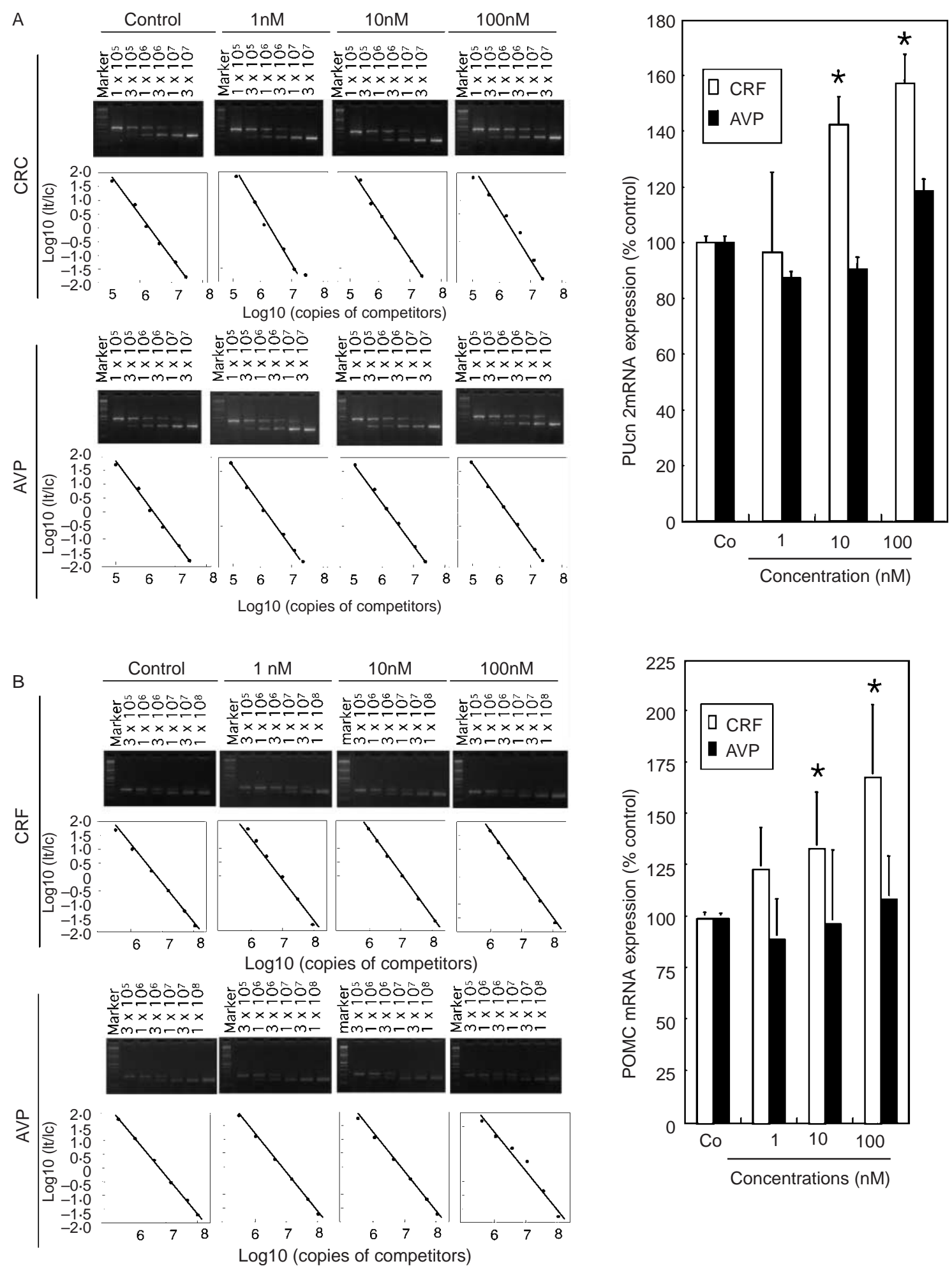

Figure 4 CRF induces Ucn 2 mRNA expression in anterior pituitary cells. Anterior pituitary cells were treated with CRF or vasopressin at concentrations ranging from 1 to $100 \mathrm{nM}$ for $4 \mathrm{~h}$. Total RNA was extracted from cells and assayed for Ucn 2 (A) and POMC (B) mRNA expression levels using competitive RT-PCR. The data shown are representatives of each competitive RT-PCR experiment. Signals were measured using NIH Image and data represent means \pm S.E.M. The number of wells for each treatment was $24 .{ }^{*} P<0 \cdot 05$, compared with control. 


\section{RT-PCR}

Total RNA was extracted from cells using Isogen according to the manufacturer's instructions (Takara, Shiga, Japan). To avoid false positive results caused by DNA contamination, a DNase treatment for $60 \mathrm{~min}$ at $37^{\circ} \mathrm{C}$ using RNase-free DNase (Takara) was performed. First, strand cDNA was synthesized using $1 \mu \mathrm{g}$ denatured total RNA under conditions of $42{ }^{\circ} \mathrm{C}$ for $30 \mathrm{~min}, 99^{\circ} \mathrm{C}$ for $5 \mathrm{~min}$, and $5{ }^{\circ} \mathrm{C}$ for 5 min using the RT-PCR kit (Takara). PCR was carried out under conditions of denaturation at $94{ }^{\circ} \mathrm{C}$ for $10 \mathrm{~s}$, annealing at $50{ }^{\circ} \mathrm{C}$ for $5 \mathrm{~s}$, and extension at $72{ }^{\circ} \mathrm{C}$ for $60 \mathrm{~s}$ for $30 \mathrm{cycles}$, using specific primers for Ucn 2 and POMC (Table 1). After amplification, the PCR products were subjected to $3 \%$ agarose gel electrophoresis, stained with $0.5 \mu \mathrm{g} / \mathrm{ml}$ ethidium bromide and then visualized under u.v. illumination. All PCR-amplified DNAs were sequenced for purposes of confirmation.

\section{Competitor construction}

Homologous competitive internal standards that shared the same primer-binding sites, but contained a shortened internal sequence with respect to the endogenous target RNA for Ucn 2 or POMC, were prepared as follows. The products resulting from PCR were subcloned into the $\mathrm{pGEM}$-T vector (Promega) and sequenced. The cloned pGEM-T vector was linearized by Nco I restriction enzyme digestion and transcribed into a cRNA template by SP6 RNA Polymerase (Promega). The DNA template was removed by RNase-free DNase I digestion at $37^{\circ} \mathrm{C}$ for $30 \mathrm{~min}$ after transcription and the cRNA product then quantified and used as an internal standard in RT-PCR for Ucn 2 or POMC.

\section{Competitive RT-PCR}

After DNase treatment, the amount of mRNA present in the samples was normalized using $\beta$-actin primers (Table 1 ) as an internal reference standard under the conditions of $94^{\circ} \mathrm{C}$ for $10 \mathrm{~s}, 60^{\circ} \mathrm{C}$ for $5 \mathrm{~s}$ and $72^{\circ} \mathrm{C}$ for $60 \mathrm{~s}$ for 30 cycles. The cycle number was determined at the point where PCR amplification is in a linear range by testing each reaction at different dilutions of cDNA for various amplification cycles. To test for possible genomic DNA contamination, either the RT enzyme or RNA was omitted from the reaction tube. To confirm, the RNA competitor was not contaminated with DNA, RT-PCR was performed using only RNA competitor $\left(10^{9}\right.$ copies $)$ at the maximum amount. The reaction mixture and RNA competitor were added to each tube. Reverse transcription reaction was then carried out under conditions of $42{ }^{\circ} \mathrm{C}$ for $30 \mathrm{~min}, 99^{\circ} \mathrm{C}$ $5 \mathrm{~min}$ and $5^{\circ} \mathrm{C} 5 \mathrm{~min}$. Next, the PCR mixture was dispensed into each tube which contains RT reactant. PCR was carried out under the following conditions: denaturation at $94{ }^{\circ} \mathrm{C}$ for $10 \mathrm{~s}$, annealing at $60^{\circ} \mathrm{C}$ for $5 \mathrm{~s}$, and primer extension at $72{ }^{\circ} \mathrm{C}$ for $60 \mathrm{~s}$ for 40 cycles. The PCR products were separated on $3 \%$ agarose gel, and visualized with ethidium bromide. The intensities of the bands of the PCR products of Ucn 2 and POMC were quantified using NIH image software. The ratio of endogenous product to each competitor area was plotted as a function of the competitor concentration added to each PCR. The concentrations of Ucn 2 and POMC mRNA were determined at the point where the ratio of endogenous production to competitor area of each gene was $1 \cdot 0$ (the equivalence point).

\section{Statistical analysis}

Statistical analyses were performed using ANOVA followed by Fisher's Protected Least Significant Difference (PLSD) using StatView 4.5 (Abacus Concepts, Inc. Berkeley, CA, USA). Cell culture in same experimental protocol was repeated two to four times and data were combined and

A

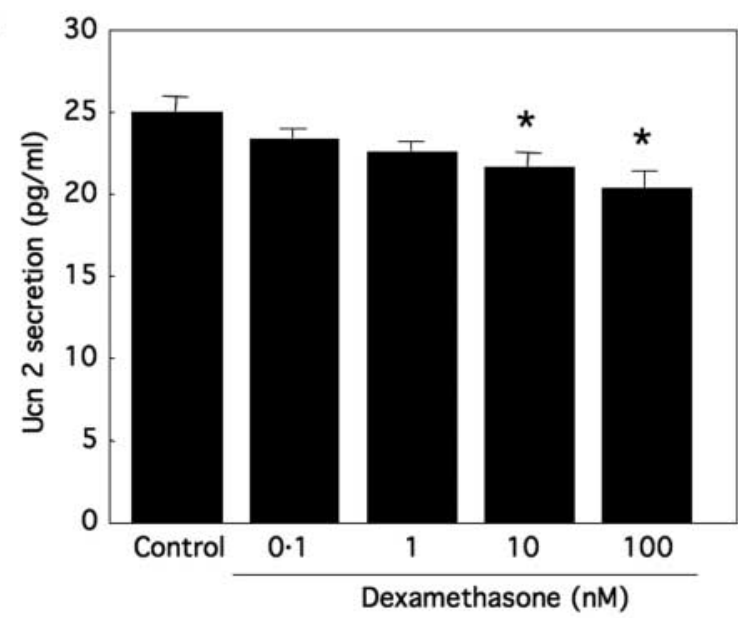

B

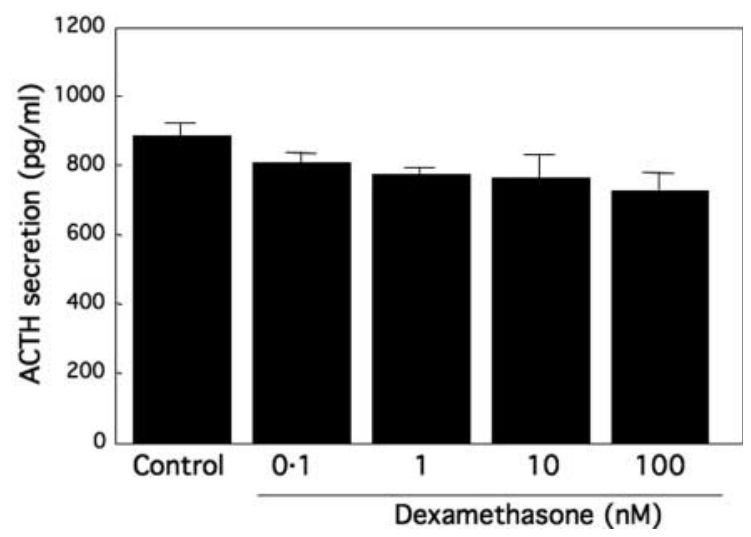

Figure 5 Dexamethasone suppresses $U \mathrm{cn} 2$ secretion from anterior pituitary cells. Anterior pituitary cells were treated with dexamethasone at concentrations ranging from $10 \mathrm{pM}$ to $100 \mathrm{nM}$ for $4 \mathrm{~h}$. Culture media were assayed for Ucn 2 using RIA with a specific antibody against mouse Ucn 2 (A) and ACTH using an ACTH IRMA kit (B). The concentrations of $U_{\mathrm{cn}} 2$ (A) and ACTH (B) are shown as means \pm S.E.M. The number of wells for each treatment was 24 . $* P<0 \cdot 05$, compared with control. 
analyzed. For competitive RT-PCR data, all results were combined for the statistical analysis and expressed as percent of controls. Statistical significance was established at the $P<0 \cdot 05$ level.

\section{Results}

Ucn 2 secretion from anterior and intermediate pituitary cells

Dilution curves of culture medium in which anterior or intermediate pituitary cells were incubated with $50 \mathrm{mM} \mathrm{KCl}$ and the extract of cultured anterior or intermediate lobe cells were almost parallel with the standard curve of Ucn 2 (Fig. 1). The basal concentrations of Ucn 2 in the culture medium of the anterior and intermediate pituitary cells were $24 \cdot 8 \pm 1 \cdot 6$ and $23 \cdot 6 \pm 1 \cdot 8 \mathrm{pg} / \mathrm{ml}$ per $10^{4}$ cells per $4 \mathrm{~h}$ respectively. When cells were depolarized with $50 \mathrm{mM} \mathrm{KCl}$ for $4 \mathrm{~h}$, the concentrations of Ucn 2 in the culture medium of the anterior and the intermediate pituitary were significantly increased to $43 \cdot 1 \pm 2 \cdot 0$ and $38 \cdot 6 \pm 2 \cdot 3 \mathrm{pg} / \mathrm{ml}$ per $10^{4}$ cells respectively (Fig. 2).
Effects of CRF and vasopressin on $m R N A$ expression and secretion of Ucn 2 in anterior pituitary cells

The secretion of Ucn 2 was increased by CRF at concentrations of 10 and $100 \mathrm{nM}$, while it was not affected by vasopressin (Fig. 3A). Under the same conditions, both CRF and vasopressin significantly increased ACTH secretion at concentrations of 1,10 and $100 \mathrm{nM}$ (Fig. 3B). The expression levels of Ucn 2 mRNA as well as POMC mRNA were significantly increased by CRF at concentrations of 10 and $100 \mathrm{nM}$, while they were not affected by vasopressin even at a concentration of $100 \mathrm{nM}$ (Fig. 4A and B).

Suppressive effect of dexamethasone on $m R N A$ expression and secretion of Ucn 2 in anterior pituitary cells

Dexamethasone significantly suppressed Ucn 2 secretion at concentrations of 10 and $100 \mathrm{nM}$ whereas it did not induce any significant change in ACTH secretion (Fig. 5). Dexamethasone significantly inhibited Ucn 2 mRNA expression levels at a concentration of $100 \mathrm{nM}$ while it also inhibited POMC mRNA expression levels at concentrations ranging from $0 \cdot 1$ to $100 \mathrm{nM}$ (Fig. 6).
A

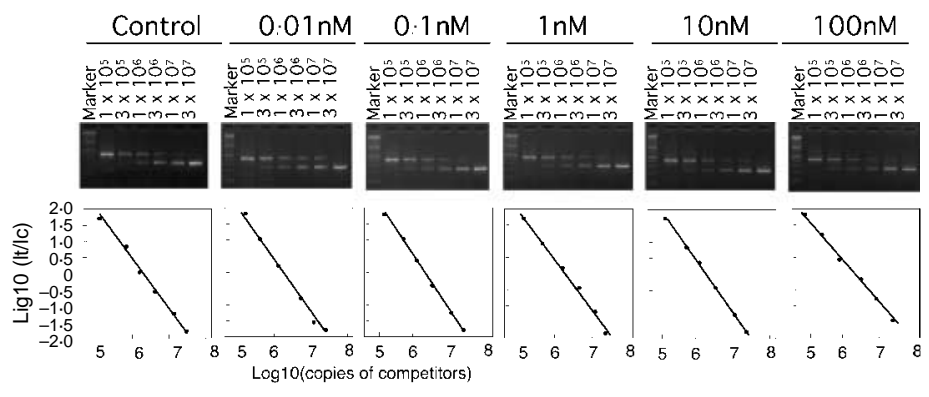

B

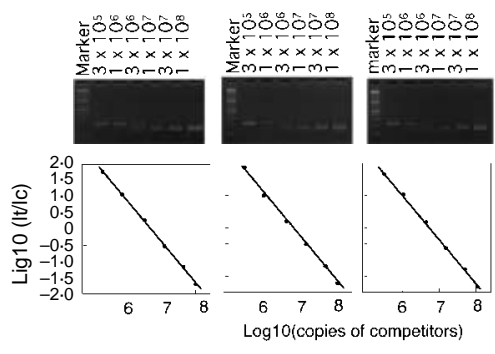

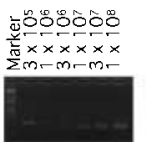

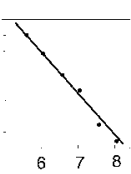

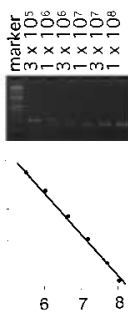
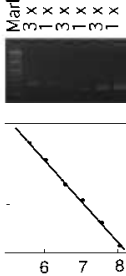

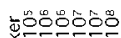
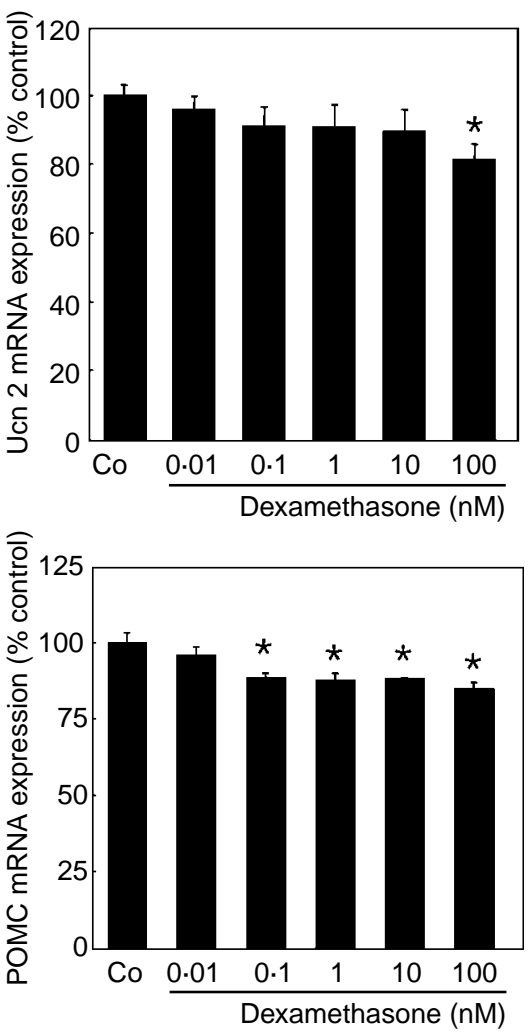

Figure 6 Dexamethasone suppresses Ucn 2 mRNA expression in anterior pituitary cells. Anterior pituitary cells were treated with dexamethasone at concentrations ranging from $0 \cdot 1 \mathrm{nM}$ to $100 \mathrm{nM}$ for $4 \mathrm{~h}$. Total RNA was extracted from cells and assayed for Ucn 2 (A) and POMC (B) mRNA expression levels using competitive RT-PCR. The data shown are representatives of each competitive RT-PCR experiment. Signals were measured using NIH Image and data represent means \pm s.E.M. The number of wells for each treatment was $24 .{ }^{*} P<0 \cdot 05$, compared with control. 
A
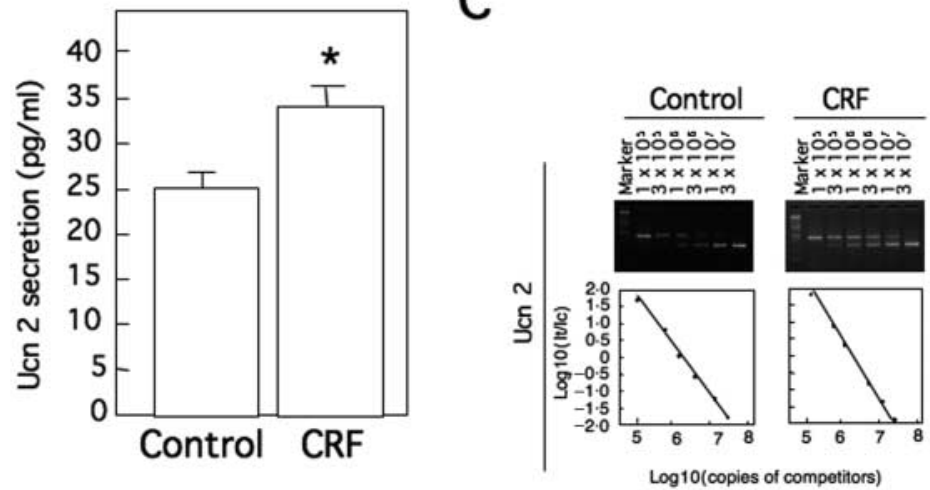

B
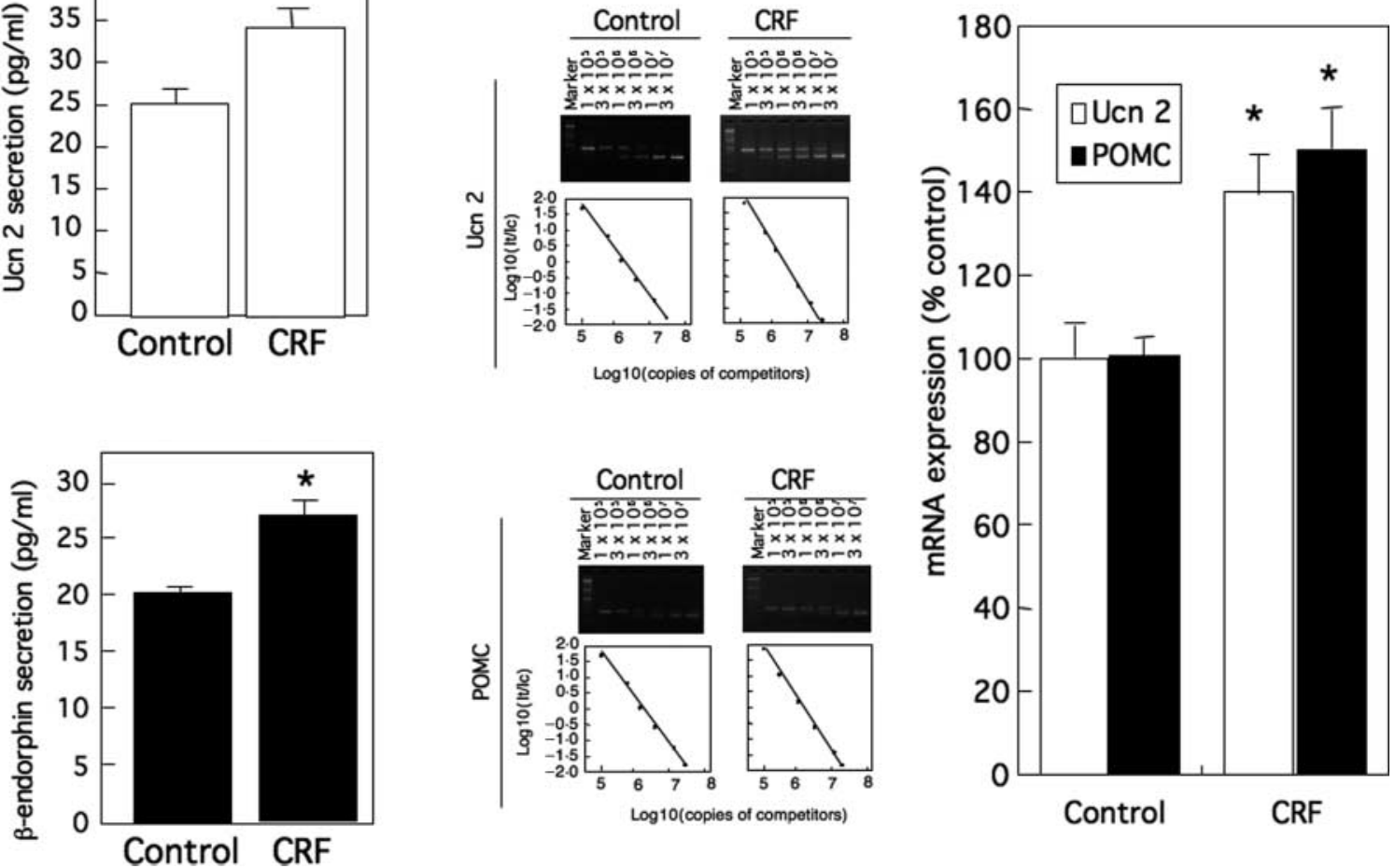

Figure $7 \mathrm{CRF}$ induces the secretion and mRNA expression of $U \mathrm{cn} 2$ in intermediate pituitary cells. Intermediate pituitary cells were treated with $10 \mathrm{nM}$ CRF for $4 \mathrm{~h}$. Culture media were assayed for Ucn 2 and $\beta$-endorphin using RIA and a rat $\beta$-endorphin EIA kit respectively (A and B). The concentrations of $U \mathrm{cn} 2$ and $\beta$-endorphin are shown as means \pm s.E.M. The number of wells for each treatment in $U \mathrm{cn} 2$ and $\beta$-endorphin assays were 16 and 12 respectively. Total RNA was extracted from cells and assayed for Ucn 2 and POMC mRNA expression levels using competitive RT-PCR (C). The data shown are representatives of each competitive RT-PCR experiment. Signals were measured using NIH Image and data represent means \pm S.E.M. The number of wells for each treatment was $12 .{ }^{*} P<0 \cdot 05$, compared with control.

Effects of CRF and dopamine on secretion and $m R N A$ expression of Ucn 2 in intermediate pituitary cells

CRF significantly increased the secretion of $\mathrm{Ucn}_{\mathrm{c}} 2$ as well as $\beta$-endorphin and the expression levels of $U \mathrm{cn} 2$ and POMC mRNA at a concentration of $10 \mathrm{nM}$ (Fig. 7). Although dopamine inhibited $\beta$-endorphin secretion at concentrations of 10 and $100 \mathrm{nM}$, it did not affect the secretion and mRNA expression levels of $U \mathrm{cn} 2$ or the expression levels of POMC mRNA at the same concentrations (Fig. 8).

\section{Discussion}

We have previously reported that Ucn 2 is biosynthesized by POMC cells in the anterior and intermediate lobe of rat pituitary (Yamauchi et al. 2005). The results of the present study indicate that Ucn 2 is secreted from both anterior and intermediate lobe cells of rat pituitary. In addition, we have shown that the mRNA expression level and secretion of $U \mathrm{cn}$ 2 in anterior lobe cells is stimulated by CRF but not by vasopressin. We also found that CRF stimulates the expression level of POMC mRNA and secretion of ACTH in anterior lobe cells, while vasopressin stimulates the secretion of ACTH but not the expression of POMC mRNA in accordance with previous reports (Giguere \& Labrie 1982, Aguilera et al. 1983). The adenylate cyclaseprotein kinase A (PKA) pathway mediates CRF-induced secretion of POMC-derived peptides, while AVP increases the secretion of POMC-derived peptides via the phospholipase C (PLC)-protein kinase C (PKC) pathway (Mason et al. 2002), indicating the intracellular signaling cascade under CRF is different from that under vasopressin. It therefore seems that the secretion of Ucn 2 is dependent on the adenylate cyclase-PKA pathway, while that of POMCderived peptides is dependent on either the adenylate cyclase-PKA or PLC-PKC pathways.

It is well known that both the secretion of POMC-derived peptides and expression level of POMC mRNA in the anterior pituitary POMC cells are suppressed by glucocorticoids (Suda et al. 1988, Levin et al. 1993, Wardlaw et al. 1998). The present study has shown that dexamethasone inhibits the secretion of Ucn 2 from the anterior pituitary lobe cells. The secretion of $\mathrm{ACTH}$ tended to be lower in the presence of dexamethasone 

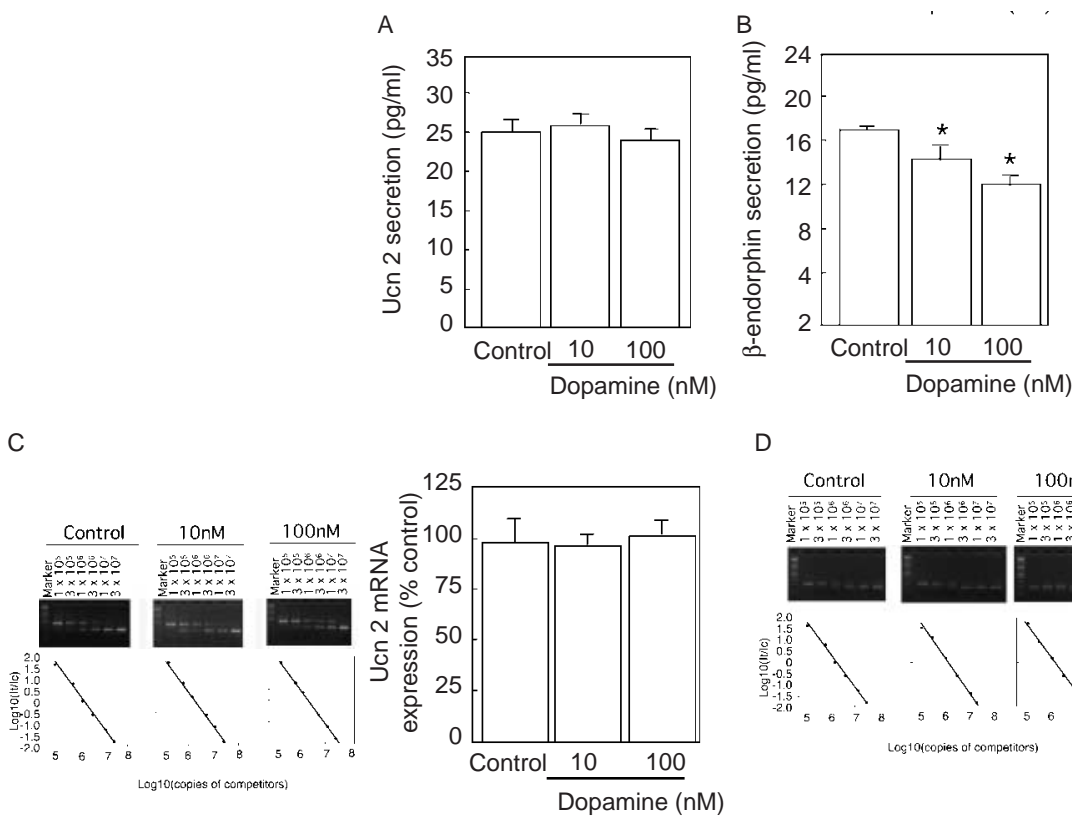

D
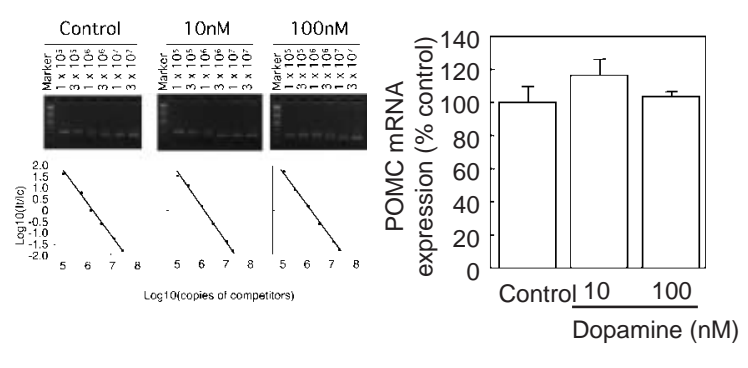

Figure 8 Dopamine does not affect the secretion or mRNA expression of Ucn 2 from intermediate pituitary cells. Intermediate pituitary cells were treated with dopamine for $4 \mathrm{~h}$. After incubation, culture media were collected and assayed for Ucn 2 (A) and $\beta$-endorphin (B) using RIA and a rat $\beta$-endorphin EIA kit respectively. The concentrations of $U \mathrm{cn} 2$ and $\beta$-endorphin are shown as means \pm S.E.M. Total RNA was extracted from cells and assayed for Ucn 2 (C) and POMC (D) mRNA expression using competitive RT-PCR. The data shown are representatives of each competitive RT-PCR experiment. Signals were measured using NIH Image and data represent means \pm S.E.M. The number of wells for each treatment was $12 .{ }^{*} P<0 \cdot 05$, compared with control.

although the decrease was not statistically significant, in accordance with previous reports showing that dexamethasone does not affect basal secretion of ACTH although it inhibits the secretion of ACTH stimulated by CRF in cultured anterior lobe cells of rat pituitary and AtT20/D16v cells (Familari \& Funder 1989, Horiba et al. 1993). In the present study, dexamethasone also inhibited the expression levels of both Ucn 2 and POMC mRNA. The actions of corticosteroids are mediated through binding to two distinct intracellular transcription factors, glucocorticoid receptor (GR) and mineralocorticoid receptor (MR). Ligand-activated GR and MR bind to a consensus simple hormone response element in the promoter region of target genes, and activate or inhibit transcription. In the pituitary, the cerebral cortex, hypothalamic paraventricular nucleus, and the hippocampus of rodents are considered to be GR-rich tissues. Although the levels of GR expression differ among reports, several studies have shown GR immunoreactivity in almost all pituitary hormone-producing cells in the rat anterior pituitary, in particular in somatotrophs, corticotrophs, and folliculostellate cells (Kononen et al. 1993). It has also been demonstrated that the levels of Ucn 2 mRNA expression in the hypothalamus and brain stem of mice tested by RT-PCR are increased by dexamethasone and decreased by adrenalectomy (Chen et al. 2003), while a report using in situ hybridization has shown no effect of adrenalectomy on the expression level of Ucn 2 mRNA in the paraventricular nucleus of rat hypothalami (Tanaka et al. 2003). Moreover, adrenalectomy significantly increases Ucn 2 mRNA expression in the skin of rats, and the expression is reversed to normal levels after corticosterone replacement (Chen et al. 2004), suggesting that Ucn 2 mRNA expression in the skin is negatively regulated by corticosterone. The same report also detected no effects of adrenalectomy on the level of Ucn 2 mRNA in the skeletal muscle. Several glucocorticoid response element (GRE) consensus sites are located in the $5^{\prime}$-untranslated region of mouse Ucn 2 sequence (Chen et al. 2003). Therefore, the effects of glucocorticoids on Ucn 2 mRNA transcription most likely differ among tissues, and Ucn 2 mRNA transcription may be negatively regulated by GR in the anterior pituitary.

The present study has shown that the secretion of $\beta$-endorphin and mRNA expression level of POMC in intermediate pituitary lobe cells are stimulated by CRF in accordance with previous reports (Loeffler et al. 1986, Saland et al. 1991), and that the secretion and mRNA expression level of Ucn 2 in intermediate lobe cells were also stimulated by CRF. The secretion of $\beta$-endorphin and the expression of POMC mRNA in intermediate lobe cells are known to be inhibited by dopamine through highly expressed $\mathrm{D}_{2}$ receptor (Cote et al. 1986, Chronwall et al. 1988, Loeffler et al. 1988, Sands et al. 1997). However, the present study showed that 
dopamine did not affect either the secretion or the mRNA expression of Ucn 2 in intermediate lobe cells, although it significantly inhibited the secretion but not mRNA expression of $\beta$-endorphin. The reason why dopamine did not inhibit the expression level of POMC mRNA may be the shorter incubation of these cells with dopamine, as intermediate lobe cells were treated with dopamine for $48 \mathrm{~h}$ in the previous study that detected the suppression of POMC mRNA expression (Loeffler et al. 1988). Since dopamine inhibited the secretion of $\beta$-endorphin but not Ucn 2 , Ucn 2 and $\beta$-endorphin appear not to be contained in the same secretory vesicles.

The role of pituitary Ucn 2 is unknown. In situ hybridization analyses and RNase protection assays have shown that $\mathrm{CRF}_{2}$ receptor mRNA is expressed in rat anterior pituitary cells (Chalmers et al. 1995, Kageyama et al. 2000). In addition, neither SRP nor Ucn 2 affects ACTH secretion from cultured rat anterior pituitary cells in vitro or in vivo (Hsu \& Hsueh 2001, Pelleymounter et al. 2004). We also found no significant effect of Ucn 2 on ACTH secretion in the cultured rat anterior pituitary cells (data not shown). These findings suggest that pituitary Ucn 2 may act on some pituitary cells other than POMC cells through a paracrine pathway and play some role in the regulatory mechanism of expression/ secretion of pituitary hormones.

In summary, the present study demonstrates that the mRNA expression level and secretion of Ucn 2 are increased by CRF in the anterior and intermediate pituitary cells, and that Ucn 2 secretion is suppressed by glucocorticoids in anterior pituitary cells.

\section{Acknowledgements}

This study was supported in part by Health and Labor Sciences Research Grants from the Ministry of Health, Labor and Welfare, and Grants-in-Aid for Scientific Research from the Ministry of Education, Science and Culture of Japan. The authors declare that there is no conflict of interest that would prejudice the impartiality of this scientific work.

\section{References}

Aguilera G, Harwood JP, Wilson JX, Morell J, Brown JH \& Catt KJ 1983 Mechanisms of action of corticotropin-releasing factor and other regulators of corticotropin release in rat pituitary cells. Journal of Biological Chemistry 258 8039-8045.

Chalmers DT, Lovenberg TW \& De Souza EB 1995 Localization of novel corticotropin-releasing factor receptor (CRF2) mRNA expression to specific subcortical nuclei in rat brain: comparison with CRF1 receptor mRNA expression. Journal of Neuroscience 15 6340-6350.

Chen R, Lewis KA, Perrin MH \& Vale WW 1993 Expression cloning of a human corticotropin-releasing-factor receptor. PNAS $\mathbf{9 0}$ 8967-8971.

Chen A, Vaughan J \& Vale WW 2003 Glucocorticoids regulate the expression of the mouse urocortin II gene: a putative connection between the corticotropin-releasing factor receptor pathways. Molecular Endocrinology 17 1622-1639.
Chen A, Blount A, Vaughan J, Brar B \& Vale W 2004 Urocortin II gene is highly expressed in mouse skin and skeletal muscle tissues: localization, basal expression in corticotropin-releasing factor receptor (CRFR) 1 - and CRFR2-null mice, and regulation by glucocorticoids. Endocrinology 145 2445-2457.

Chen A, Perrin M, Brar B, Li C, Jamieson P, Digruccio M, Lewis K \& Vale W 2005 Mouse corticotropin-releasing factor receptor type $2 \alpha$ gene: isolation, distribution, pharmacological characterization and regulation by stress and glucocorticoids. Molecular Endocrinology 19 441-458.

Chronwall BM, Hook GR \& Millington WR 1988 Dopaminergic regulation of the biosynthetic activity of individual melanotropes in the rat pituitary intermediate lobe: a morphometric analysis by light and electron microscopy and in situ hybridization. Endocrinology 123 1992-2002.

Cote TE, Felder R, Kebabian JW, Sekura RD, Reisine T \& Affolter HU 1986 D-2 dopamine receptor-mediated inhibition of pro-opiomelanocortin synthesis in rat intermediate lobe. Abolition by pertussis toxin or activators of adenylate cyclase. Journal of Biological Chemistry 261 4555-4561.

Familari M \& Funder JW 1989 Isolated pituitary cells: glucocorticoids do not rapidly suppress ACTH secretion in response to CRF. American Journal of Physiology 256 E145-E151.

Giguere V \& Labrie F 1982 Vasopressin potentiates cyclic AMP accumulation and $\mathrm{ACTH}$ release induced by corticotropin-releasing factor (CRF) in rat anterior pituitary cells in culture. Endocrinology 111 1752-1754.

Horiba N, Nicholson WE, Ch'ng JL \& Orth DN 1993 Chromogranin A does not mediate glucocorticoid inhibition of adrenocorticotropin secretion. Endocrinology 132 1585-1592.

Hsu SY \& Hsueh AJ 2001 Human stresscopin and stresscopin-related peptide are selective ligands for the type 2 corticotropin-releasing hormone receptor. Nature Medicine 7 605-611.

Kageyama K, Gaudriault GE, Bradbury MJ \& Vale WW 2000 Regulation of corticotropin-releasing factor receptor type $2 \beta$ messenger ribonucleic acid in the rat cardiovascular system by urocortin, glucocorticoids, and cytokines. Endocrinology 141 2285-2293.

Kononen J, Honkaniemi J, Gustafsson JA \& Pelto-Huikko M 1993 Glucocorticoid receptor colocalization with pituitary hormones in the rat pituitary gland. Molecular and Cellular Endocrinology 93 97-103.

Kostich WA, Chen A, Sperle K \& Largent BL 1998 Molecular identification and analysis of a novel human corticotropin-releasing factor (CRF) receptor: the CRF2 $\gamma$ receptor. Molecular Endocrinology 12 1077-1085.

Levin N, Wallace C, Bengani N, Blum M, Farnworth P, Smith AI \& Roberts JL 1993 Ovine anterior pituitary proopiomelanocortin gene expression is not increased by ACTH secretagogues in vitro. Endocrinology 132 1692-1700.

Lewis K, Li C, Perrin MH, Blount A, Kunitake K, Donaldson C, Vaughan J, Reyes TM, Gulyas J, Fischer W et al. 2001 Identification of urocortin III, an additional member of the corticotropin-releasing factor (CRF) family with high affinity for the CRF2 receptor. PNAS 98 7570-7575.

Liaw CW, Lovenberg TW, Barry G, Oltersdorf T, Grigoriadis DE \& de Souza EB 1996 Cloning and characterization of the human corticotropin-releasing factor-2 receptor complementary deoxyribonucleic acid. Endocrinology 137 $72-77$.

Loeffler JP, Kley N, Pittius CW \& Hollt V 1986 Regulation of proopiomelanocortin (POMC) mRNA levels in primary pituitary cultures. NIDA Research Monograph 75 397-400.

Loeffler JP, Demeneix BA, Kley NA \& Hollt V 1988 Dopamine inhibition of proopiomelanocortin gene expression in the intermediate lobe of the pituitary. Interactions with corticotropin-releasing factor and the betaadrenergic receptors and the adenylate cyclase system. Neuroendocrinolog $\mathbf{4 7}$ 95-101.

Mason D, Hassan A, Chacko S \& Thompson P 2002 Acute and chronic regulation of pituitary receptors for vasopressin and corticotropin releasing hormone. Archives of Physiology and Biochemistry 110 74-89.

Pelleymounter MA, Joppa M, Ling N \& Foster AC 2004 Behavioral and neuroendocrine effects of the selective CRF2 receptor agonists urocortin II and urocortin III. Peptides 25 659-666.

Reyes TM, Lewis K, Perrin MH, Kunitake KS, Vaughan J, Arias CA, Hogenesch JB, Gulyas J, Rivier J, Vale WW et al. 2001 Urocortin II: a member of the corticotropin-releasing factor (CRF) neuropeptide family that is selectively bound by type 2 CRF receptors. PNAS $\mathbf{9 8} 2843-2848$. 
Saland LC, Carr JA, Samora A, Benavidez S \& Tejeda D 1991 Interaction of corticotropin-releasing factor (CRF) and alpha-helical CRF on rat neurointermediate lobes: in vitro studies. Neuropeptides 19 213-221.

Sands SA, Dickerson DS, Morris SJ \& Chronwall BM 1997 Dopamine D2 receptor stimulation alters G-protein expression in rat pituitary intermediate lobe melanotropes. Endocrine 6 325-333.

Shibasaki T, Kiyosawa Y, Masuda A, Nakahara M, Imaki T, Wakabayashi I, Demura H, Shizume K \& Ling N 1984 Distribution of growth hormone-releasing hormone-like immunoreactivity in human tissue extracts. Journal of Clinical Endocrinology and Metabolism $59263-268$

Suda T, Tozawa F, Yamada M, Ushiyama T, Tomori N, Sumitomo T, Nakagami Y \& Shizume K 1988 In vitro study on proopiomelanocortin messenger RNA levels in cultured rat anterior pituitary cells. Life Sciences 42 1147-1152.

Tanaka Y, Makino S, Noguchi T, Tamura K, Kaneda T \& Hashimoto K 2003 Effect of stress and adrenalectomy on urocortin II mRNA expression in the hypothalamic paraventricular nucleus of the rat. Neuroendocrinology 78 1-11.
Vaughan J, Donaldson C, Bittencourt J, Perrin MH, Lewis K, Sutton S, Chan R, Turnball AV, Lovejoy D, Rivier C, Rivier J, Sawchenko PE \& Vale W 1995 Urocortin, a mammalian neuropeptide related to fish urotensin I and to corticotropin-releasing factor. Nature 378 287-292.

Wang TY, Chen XQ, Du JZ, Xu NY, Wei CB \& Vale WW 2004 Corticotropin-releasing factor receptor type 1 and $2 \mathrm{mRNA}$ expression in the rat anterior pituitary is modulated by intermittent hypoxia, cold and restraint. Neuroscience 128 111-119.

Wardlaw SL, McCarthy KC \& Conwell IM 1998 Glucocorticoid regulation of hypothalamic proopiomelanocortin. Neuroendocrinology 67 51-57.

Yamauchi N, Otagiri A, Nemoto T, Sekino A, Oono H, Kato I, Yanaihara C \& Shibasaki T 2005 Distribution of urocortin 2 in various tissues of the rat. Journal of Neuroendocrinology 17 656-663.

Received in final form 28 November 2006

Accepted 30 November 2006

Made available online as an Accepted Preprint 11

December 2006 